\title{
Enterobacter taylorae
}

National Cancer Institute

\section{Source}

National Cancer Institute. Enterobacter taylorae. NCI Thesaurus. Code C86363.

A species of facultatively anaerobic, Gram negative, rod shaped bacterium in the phylum Proteobacteria. This species is oxidase negative, catalase positive, reduces nitrate, indole negative and produce gas during fermentation. E. taylorae is an emerging opportunistic, nosocomial borne pathogen. 